\title{
Properties of Adherence Factor Plasmids of Enteropathogenic Escherichia coli and the Effect of Host Strain on Expression of Adherence to HEp-2 Cells
}

\author{
By MOYRA M. MCCONNELL, ${ }^{*}$ HENRIK CHART, SYLVIA M. SCOTLAND, \\ HENRY R. SMITH, GERALDINE A. WILLSHAW AND BERNARD ROWE \\ Division of Enteric Pathogens, Central Public Health Laboratory, 61 Colindale Avenue, \\ London NW9 $5 H T, U K$
}

(Received 2 September 1988; revised 20 December 1988; accepted 12 January 1989)

\begin{abstract}
EPEC adherence factor (EAF) plasmids from three strains of enteropathogenic Escherichia coli (EPEC) - E2347/69 (O127:H6), E20517 (O111:H2) and E24582 (O142:H6) - were examined. The EAF plasmids were all marked with ampicillin resistance by transposition of Tn 801 to give pDEP1, pDEP2 and pDEP11, respectively. All three plasmids showed incompatibility with an $\mathrm{FI}_{\mathrm{me}}$ and an FIV plasmid and had some similarity in restriction enzyme digest patterns. Plasmid pDEP1 differed from pDEP2 and pDEP11 in being autotransferring and fertility-inhibition positive. An EAF probe consisting of a $1 \mathrm{~kb}$ BamHI-SalI restriction endonuclease fragment of the prototype EAF-associated plasmid pMAR2 hybridized to similar-sized Sall-BamHI fragments of pDEP1 and pDEP11 but to a different-sized fragment of plasmid pDEP2. Loss of the EAF plasmids from EPEC strains resulted in a marked reduction in the ability of these strains to adhere to HEp-2 cells. The EAF-plasmid-negative variants did not express a $94 \mathrm{kDa}$ outer-membrane protein (OMP). When these EAF plasmids were reintroduced into EAFplasmid-negative EPEC strains a high level of adherence equivalent to that of the parent EPEC strains was restored and a $94 \mathrm{kDa}$ OMP was usually expressed. However, when EAF plasmids were transferred into $E$. coli $\mathrm{K} 12$ or non-EPEC $E$. coli the host strains either did not adhere or adhered poorly to the HEp-2 cells. These transconjugants did not express a $94 \mathrm{kDa}$ OMP.
\end{abstract}

\section{INTRODUCTION}

The term enteropathogenic Escherichia coli (EPEC) is commonly used to describe E. coli of certain serotypes that have been epidemiologically implicated in diarrhoeal disease (Taylor, 1961). These E. coli are an important cause of diarrhoea in infants in developing countries and still cause sporadic cases and occasionally outbreaks of infantile enteritis in industrialized countries. EPEC do not have recognized virulence factors such as the ability to produce heatstable or heat-labile enterotoxins or Vero cytotoxins or to invade the gut mucosa, and are generally identified by serotyping. The most common $\mathrm{O}$ serogroups are $\mathrm{O} 55, \mathrm{O} 86, \mathrm{O} 111, \mathrm{O} 114$, O125, O126, O127, O128 and O142 (Edelman \& Levine, 1983; Gross \& Rowe, 1985).

Cravioto et al. (1979) reported that $80 \%$ of EPEC strains adhered to HEp-2 cells and that this adherence was significantly more common among EPEC than among enterotoxigenic $E$. coli or $E$. coli isolates from healthy individuals. Three patterns of adherence to HeLa and HEp-2 cells have now been described; localized, diffuse and 'aggregative' (Scaletsky et al., 1984; Nataro et $a l ., 1985 b, 1987 a$ ). Most work has been done on strains which adhere to HEp-2 cells in a localized manner like E2347/69 and E2348/69 (Cravioto et al., 1979). The ability of strain

\footnotetext{
Abbreviations: EPEC, enteropathogenic Escherichia coli; EAF, EPEC adherence factor; OMP, outer-membrane protein.
} 
E2348/69 to adhere was shown to be coded for by a 60 MDa conjugative plasmid termed pMAR2 (Baldini et al., 1983).

Certain properties of E2348/69 and its pMAR2-minus variant have been compared. In volunteer studies diarrhoea occurred in nine of ten healthy adults challenged with E2348/69 and in two of nine who received the plasmid-minus variant (Levine et al., 1985). Knutton et al. $(1987 b$ ) have compared the ability of E2348/69 and its pMAR2-negative derivative to adhere to HEp- 2 cells, isolated human enterocytes and cultured human intestinal mucosal biopsy tissues. They found that the plasmid-cured derivative was non-adherent in the HEp-2 cell and isolated enterocyte assays after $3 \mathrm{~h}$, but did exhibit some adherence to cultured mucosa after 9 to $12 \mathrm{~h}$, producing identical lesions although not as extensive, as those produced by the parent strain. Chart et al. (1988) in a $6 \mathrm{~h}$ assay found that a plasmid-negative derivative of E2347/69 showed some ability to adhere to HEp-2 cells. An E. coli K12 strain containing pMAR2 adhered to HEp-2 cells but did not show the intimate attachment of the parent strain (Knutton et al., $1987 a$ ). The latter authors concluded that plasmid pMAR2 coded for an adhesin, but that other, possibly chromosomally encoded factors were required for EPEC to achieve the characteristic mode of intimate cell attachment.

The name EPEC adherence factor (EAF) has been applied to the adhesin of strain E2348/69 which contains plasmid pMAR2 (Levine et al., 1985). A region of pMAR2 which is required for the expression of the EAF adhesin has been identified and a DNA fragment lying within this region has been used as a specific probe to detect EAF genes in E. coli (Nataro et al., 1985a). By this means, it has been shown that EAF genes are present in strains which have the localized adherence phenotype (Nataro et al., 1985b; Echeverria et al., 1987; Chart et al., 1988), and that these genes are usually encoded by plasmids varying in size from 55 to $70 \mathrm{MDa}$ (Nataro et al., $1985 \mathrm{~b}$ ). Strains carrying an EAF plasmid usually produce an outer-membrane protein (OMP) of $94 \mathrm{kDa}$ (Levine et al., 1985; Chart et al., 1988). Antibodies to the $94 \mathrm{kDa}$ OMP were detected in the sera of volunteers infected with E2348/69 suggesting that this protein might have a role in pathogenicity (Levine et al., 1985). EAF-positive EPEC of serogroups O111, O119 and O142 possessed a protein of about $94 \mathrm{kDa}$ that reacted with antibodies in these human sera (Levine $e t$ al., 1985). However, an antiserum raised in rabbits to a HEp-2 adhesive strain of EPEC of serotype $\mathrm{O} 111: \mathrm{H} 2$ did not react with the $94 \mathrm{kDa}$ OMP of all EPEC strains, indicating some interstrain variability in this protein (Chart et al., 1988).

Two reports have described plasmids coding for both localized adherence and drug resistance. Two autotransferring adherence plasmids from $E$. coli strains of serogroup O55 coded for ampicillin resistance and ampicillin, chloramphenicol, kanamycin and sulphadiazine resistance, respectively (Laporta et al., 1986). A plasmid transferred from an EPEC strain belonging to serotype $0111: \mathrm{H}^{-}$encoded the expression of the O111-specific side-chain of the lipopolysaccharide as well as drug resistance and localized adherence (Riley et al., 1987).

In the present study EAF plasmids were transferred from three EPEC strains of different serotypes to $E$. coli $\mathrm{K} 12$ and some of their properties compared. The expression of adhesion to HEp- 2 cells when these EAF plasmids were transferred to $E$. coli of different serotypes were also compared to examine the relationship of plasmid and chromosomally encoded factors.

\section{METHODS}

Bacterial strains. The three EPEC strains used as sources of EAF plasmids were isolated from outbreaks of infantile gastroenteritis; E20517 and E2347/69 in the UK (Chart et al., 1988) and strain E24582 in the Netherlands (Gerards et al., 1984). Strain E24583 was isolated from the same outbreak as E24582 but did not adhere to HEp-2 cells (Table 1). Strain E2347/69 was isolated from the same outbreak as E2348/69, the strain from which the prototype EAF plasmid pMAR2 was isolated; these strains have identical properties. Strain E20517 was resistant to chloramphenicol, kanamycin, streptomycin, sulphonamides and tetracycline, E2347/69 to streptomycin and sulphonamides and E24582 and E24583 to ampicillin, chloramphenicol, kanamycin, streptomycin, sulphonamides and tetracycline. Table 1 also lists $E$. coli $\mathrm{K} 12$ and wild-type E. coli, which do not adhere to HEp-2 cells, that were used as recipients for the EAF plasmids.

Tests for resistance to antibacterial drugs and colicin E2 and for colicin, enterobactin and aerobactin production. Strains were tested for drug resistance by the methods of Anderson \& Threlfall (1974). Colicin E2 resistance and colicinogeny were detected by the agar overlay method of Frédéricq (1957). The ability of strains to produce 
Table 1. Properties of E. coli strains

\begin{tabular}{|c|c|c|c|c|c|c|c|c|c|}
\hline \multirow{3}{*}{$\begin{array}{l}\text { Strain } \\
\text { no. } \\
\text { E20517 } \\
60 \text { R556 }\end{array}$} & \multirow{3}{*}{$\begin{array}{l}\text { Serotype } \\
\text { O111:H2 }\end{array}$} & \multirow{3}{*}{$\begin{array}{l}\quad \begin{array}{l}\text { Source } \\
\text { of strain* }\end{array} \\
\text { Outbreak } \\
\text { 58R689 }\end{array}$} & \multicolumn{2}{|c|}{$\begin{array}{l}\text { Adherence to } \\
\text { HEp-2 cells } \dagger\end{array}$} & \multirow{3}{*}{$\begin{array}{c}\text { Reaction with } \\
\text { EAF probe }+ \\
+ \\
-\end{array}$} & \multirow{2}{*}{\multicolumn{4}{|c|}{$\begin{array}{l}\text { Plasmid content } \\
\text { (MDa) }\end{array}$}} \\
\hline & & & \multirow{2}{*}{$\begin{array}{c}3 \mathrm{~h} \\
68 \\
1 \mathrm{~S}\end{array}$} & \multirow{2}{*}{$\begin{array}{c}6 \mathrm{~h} \\
100 \\
12 \mathrm{~S}\end{array}$} & & & & & \\
\hline & & & & & & 46 & $\begin{array}{l}38 \\
30\end{array}$ & $\begin{array}{l}32 \\
24\end{array}$ & $\begin{array}{l}<2 \\
<2\end{array}$ \\
\hline $\begin{array}{l}\text { E2347/69 } \\
\text { 60R317 }\end{array}$ & $27: \mathrm{H} 6$ & $\begin{array}{l}\text { Outbreak } \\
\text { E2347/69 }\end{array}$ & $\begin{array}{l}48 \\
3 S\end{array}$ & $\begin{array}{r}100 \\
13\end{array}$ & $\begin{array}{l}+ \\
-\end{array}$ & 60 & & & $\begin{array}{l}4 \cdot 1 \\
4 \cdot 1\end{array}$ \\
\hline $\begin{array}{l}\text { E24582 } \\
\text { E24583 }\end{array}$ & $\mathrm{O} 142: \mathrm{H}$ & Outbreak§ & $\begin{array}{r}72 \\
0\end{array}$ & $\begin{array}{r}100 \\
0\end{array}$ & $\begin{array}{l}+ \\
-\end{array}$ & 61 & $\begin{array}{l}40 \\
43\end{array}$ & & $\begin{array}{l}3 \cdot 3 \\
3 \cdot 3\end{array}$ \\
\hline E27657 & $\mathrm{O} 128: \mathrm{H} 2$ & $\begin{array}{l}\text { Infant with } \\
\text { diarrhoea }\end{array}$ & 0 & $2 S$ & - & 76 & & & \\
\hline $\mathrm{E} 2722 / 1$ & $\begin{array}{l}\mathrm{O} 40: \mathrm{H} 3 \\
\mathrm{O} 1 \cdot \mathrm{H} 48\end{array}$ & Healthy infant & $\begin{array}{l}0 \\
0\end{array}$ & $\begin{array}{l}0 \\
0\end{array}$ & - & $\begin{array}{l}32 \\
41\end{array}$ & & 3 & $<3$ \\
\hline E2698/1 & $\begin{array}{l}\mathrm{O} 71: \mathrm{H} 48 \\
\mathrm{O} 99 \cdot \mathrm{H} 4\end{array}$ & Healthy infant & $\begin{array}{l}0 \\
3 \mathrm{~S}\end{array}$ & $\begin{array}{l}0 \\
7 \mathrm{~S}\end{array}$ & $\overline{-}$ & $\begin{array}{l}41 \\
40\end{array}$ & & & \\
\hline $\begin{array}{l}\mathrm{E} 2939 / 3 \\
14 R 519\end{array}$ & $\begin{array}{l}\mathrm{O} 99: \mathrm{H} 4 \\
\text { O rough }: \mathrm{H} 48\end{array}$ & $\begin{array}{l}\text { Healthy infant } \\
\text { E. coli } \mathrm{K} 12\end{array}$ & $\begin{array}{l}3 \mathrm{~S} \\
0\end{array}$ & $\begin{array}{l}15 \\
0\end{array}$ & - & 40 & & $\begin{array}{r}22 \\
\text { None }\end{array}$ & \\
\hline
\end{tabular}

* Outbreaks of infantile gastroenteritis; 58R689 is a chloramphenicol-, kanamycin- and tetracycline-sensitive derivative of E20517 with the same plasmid content as 60R556 plus the 46 MDa plasmid of E20517.

$\dagger$ The results are expressed as the percentage of $\mathrm{HEp}-2$ cells with at least one localized cluster consisting of at least 50 adherent bacteria. When percentage is followed by $\mathrm{S}$ most cells showed a single cluster of less than 10 bacteria.

‡ Southern hybridization at 'high' stringency with a $1 \mathrm{~kb}$ Sall-BamHI restriction endonuclease fragment of pMAR2, the prototype EAF plasmid (Baldini et al., 1983).

$\S$ Both isolates from the same outbreak.

siderophores was assessed by growing bacteria in Tris/succinate medium and testing for the phenolic siderophore enterobactin and the hydroxamate siderophore aerobactin as described by Griffiths et al. (1985).

$H E p-2$ cell adhesion. The ability of strains of $E$. coli to adhere to HEp-2 cells in the presence of D-mannose was determined using the method of Scotland et al. (1983). Either a $3 \mathrm{~h}$ incubation period for bacterial adherence, or a 6 $\mathrm{h}$ period in which the HEp-2 cells were washed after $3 \mathrm{~h}$ and the tissue culture medium replaced before continuing incubation for a further $3 \mathrm{~h}$ was used. In tests with $E$. coli $\mathrm{K} 12$, which grew less well in the tissue culture medium, the washing of the cells at $3 \mathrm{~h}$ was omitted, and tests were done in an atmosphere of $95 \%(\mathrm{v} / \mathrm{v})$ air and $5 \%(\mathrm{v} / \mathrm{v})$ $\mathrm{CO}_{2}$.

Plasmid DNA studies. Plasmid DNA was partially purified from the wild-type strains and from E. coli $\mathrm{K} 12$ derivatives by the method of Birnboim \& Doly (1979) and analysed by electrophoresis on vertical slab gels containing $0.6 \%(\mathrm{w} / \mathrm{v})$ agarose (Sigma, type II); plasmids of known molecular masses were separated on the same gels. Purified plasmid DNA from E. coli K 12 and wild-type strains was prepared by the alkaline SDS lysis method (Maniatis et al., 1982) followed by centrifugation in caesium chloride-ethidium bromide density gradients. Plasmid DNA was treated with restriction enzymes $E c o$ RV, PvuII and Sall plus BamHI and fragments were separated by gel electrophoresis as described previously (Willshaw et al., 1985).

DNA hybridization. The EAF probe consisted of a $1 \mathrm{~kb}$ BamHI-Sall restriction fragment isolated from plasmid pMAR22 which was derived from the plasmid pMAR2 (Nataro et al., 1985a). It was labelled with deoxyadenosine $5^{\prime}-\alpha-\left[{ }^{3} s\right.$ S]thiotriphosphate by the random primer method (Feinberg \& Vogelstein, 1983). Strains were prepared for colony hybridization as described by Maniatis et al. (1982). Transfer of DNA fragments to nylon membranes (Hybond-N, Amersham) was by the method of Southern (1975). Hybridization and washing at 'high' stringency were done as described by Willshaw et al. (1985).

Fertility inhibition. Broth cultures of strains carrying an EAF plasmid and the $\mathrm{F}$ factor marked with tetracycline resistance, plasmid F-Tc (Anderson et al., 1977) were tested with phage $\mu 2$ in surface spot tests. Plasmids that cause fertility inhibition $\left(\mathrm{f}^{+}\right)$inhibit synthesis of $\mathrm{F}$ fimbriae and therefore reduce or abolish visible lysis of the culture by phage $\mu 2$ (Anderson \& Threlfall, 1974).

Transfer of plasmids from EPEC. Strains E2347/69, E20517 and E24582 were tested for their ability to transfer drug resistance to $E$. coli K 12 strain 14R519 by overnight mating of equal volumes of nutrient broth cultures containing approximately $10^{8}$ cells $\mathrm{ml}^{-1}$. Transconjugants were selected on MacConkey agar plates containing the appropriate antibiotic and nalidixic acid to counter-select against the donor.

Strains E2347/69, E20517 and E24582 were tested for the presence of transfer factors by attempting to mobilize the non-autotransferring plasmids NTP2 and NTP107 into 14R519 (Anderson \& Threlfall, 1974). Plasmid NTP2 codes for streptomycin and sulphonamide resistance and NTP107 for kanamycin resistance (McConnell et al., 1980). 
The F-Tc plasmid was transferred into E2347/69. This strain was used as a donor when F-Tc was transferred into 14R519. Transconjugants were examined for co-transfer of a plasmid coding for fertility inhibition. These transconjugants were then examined for their ability to adhere to HEp- 2 cells, for hybridization with the EAF probe and for plasmid content.

Derivatives of E20517 and E24582 which had lost tetracycline resistance were selected by replica plating. Plasmids in these two tetracycline-sensitive derivatives were marked with the ampicillin-resistance transposon Tn801 using a temperature-sensitive derivative of plasmid RP1 (pMR5) (Robinson et al., 1980). Plasmid F-Tc was transferred into the wild-type strain and used to mobilize the Tn801-carrying plasmids into 14R519. The transconjugants were tested for their ability to adhere to HEp-2 cells, for hybridization with the EAF probe and for plasmid content.

The transconjugants from the crosses where the tetracycline-sensitive derivatives of E20517 and E2347/69 were used as donors were also tested for co-transfer of streptomycin and sulphonamide resistance. Transconjugants carrying EAF plasmids from all three crosses were tested for tube agglutination with $\mathrm{O} 111-, \mathrm{O} 127-$ and $\mathrm{O} 142-$ specific antisera to see if they expressed the O-polysiccharide side-chains.

Transfer of EAF plasmids to E. coli of different serotypes. The Tn801-marked EAF plasmids were transferred to a variety of $E$. coli recipients by overnight crosses as previously described, using as donor strains $E$. coli $\mathrm{K} 12$ carrying an autotransferring EAF plasmid or a non-autotransferring EAF plasmid and the R factor F-Tc to mobilize the EAF plasmid. Recipients were selected on MacConkey agar plates containing ampicillin $\left(100 \mu \mathrm{g} \mathrm{ml}^{-1}\right)$ and colicin E2 $\left(10^{3}\right.$ units $\left.\mathrm{ml}^{-1}\right)$, to counter-select against the donor. The ampicillin-resistant transconjugants were tested for the presence of the EAF plasmid by DNA probe tests for their ability to adhere to HEp- 2 cells and for plasmid DNA content.

Incompatibility tests. The EAF plasmid from E2347/69 was marked with ampicillin resistance by $\operatorname{Tn} 801$ transposition as described by Robinson et al. (1980). Drug-resistance plasmids of the $\mathrm{F}$ group were used in

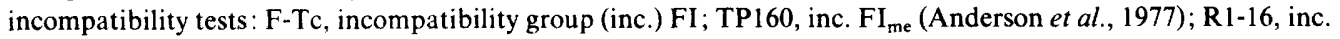
FII (Frydman \& Meynell, 1969); and TP129, inc. FIV (Hedges \& Datta, 1972). They were transferred into E. coli K12 strains carrying the Tn 801 -marked EAF plasmids to test the ability of the two plasmids to co-exist (Smith et al., 1983). Five to eight hundred colonies were tested for stability of the plasmids.

Isolation of HEp-2 non-adherent variants of EPEC. Variants of E2347/69 and E20517 which had lost the EAF plasmid were isolated by transferring an incompatble drug-resistance plasmid TP129 into these EPEC. Transconjugants were examined for loss of the unmarked or marked EAF plasmid by testing for drug resistance, then HEp- 2 adhesion and plasmid DNA content. A colony without the R factor was then isolated by looking for drug-sensitive segregants.

Isolation of outer membranes. Bacterial outer membranes were prepared as described previously (Chart \& Griffiths, 1985) using the protease inhibitor PMSF (Chart et al., 1988) and proteins separated by SDS-PAGE by the method of Laemmli (1970). Proteins were stacked using $4.5 \%(w / v)$ acrylamide gels and separated in $10 \%(w / v)$ acrylamide gels. Outer membranes were prepared on at least three occasions and each preparation was separated by SDS-PAGE at least twice.

Immunoblotting. Immunoblotting was done as described previously (Chart et al., 1988) with the exception that OMPs were separated on SDS-PAGE gels with a $10 \%(\mathrm{w} / \mathrm{v})$ acrylamide separation gel, and profiles transferred using a constant current of $0.2 \mathrm{~A}(16 \mathrm{~h})$. An antiserum prepared against $E$. coli E20513 and containing antibodies to the $94 \mathrm{kDa}$ protein was used for immunoblotting as described previously (Chart et al., 1988).

Isolation of lipopolysaccharide. Lipopolysaccharide (LPS) for SDS-PAGE was prepared from strains of $E$. coli by proteinase $\mathrm{K}$ digestion (Hitchcock \& Brown, 1983). LPS profiles analysed by SDS-PAGE were stained by a silver technique (Tsai \& Frasch, 1982). The LPS from $200 \mu \mathrm{g}$ (wet wt) of whole bacterial cells was applied to each lane for SDS-PAGE.

\section{RESULTS}

\section{Properties of EPEC strains}

The three strains E2347/69, E20517 and E24582 all showed localized adherence to HEp-2 cells, hybridized with the EAF probe and expressed an OMP of $94 \mathrm{kDa}$ (Table 1 ; Fig. 1, lanes 1 , 2 and 3). All three EPEC were drug resistant and produced enterobactin, but did not produce colicin or aerobactin. They were resistant to colicin E2.

\section{Transfer of plasmids from EPEC}

The drug-resistance markers of E2347/69, E20517 and E24582 were not autotransferable. E20517 and E24582 both contained transfer factors but these did not code for HEp-2 adherence or hybridize with the EAF probe. The transfer factor from E20517 was a 30 to $32 \mathrm{MDa}$ plasmid and that from E24582, a plasmid of about $40 \mathrm{MDa}$. 


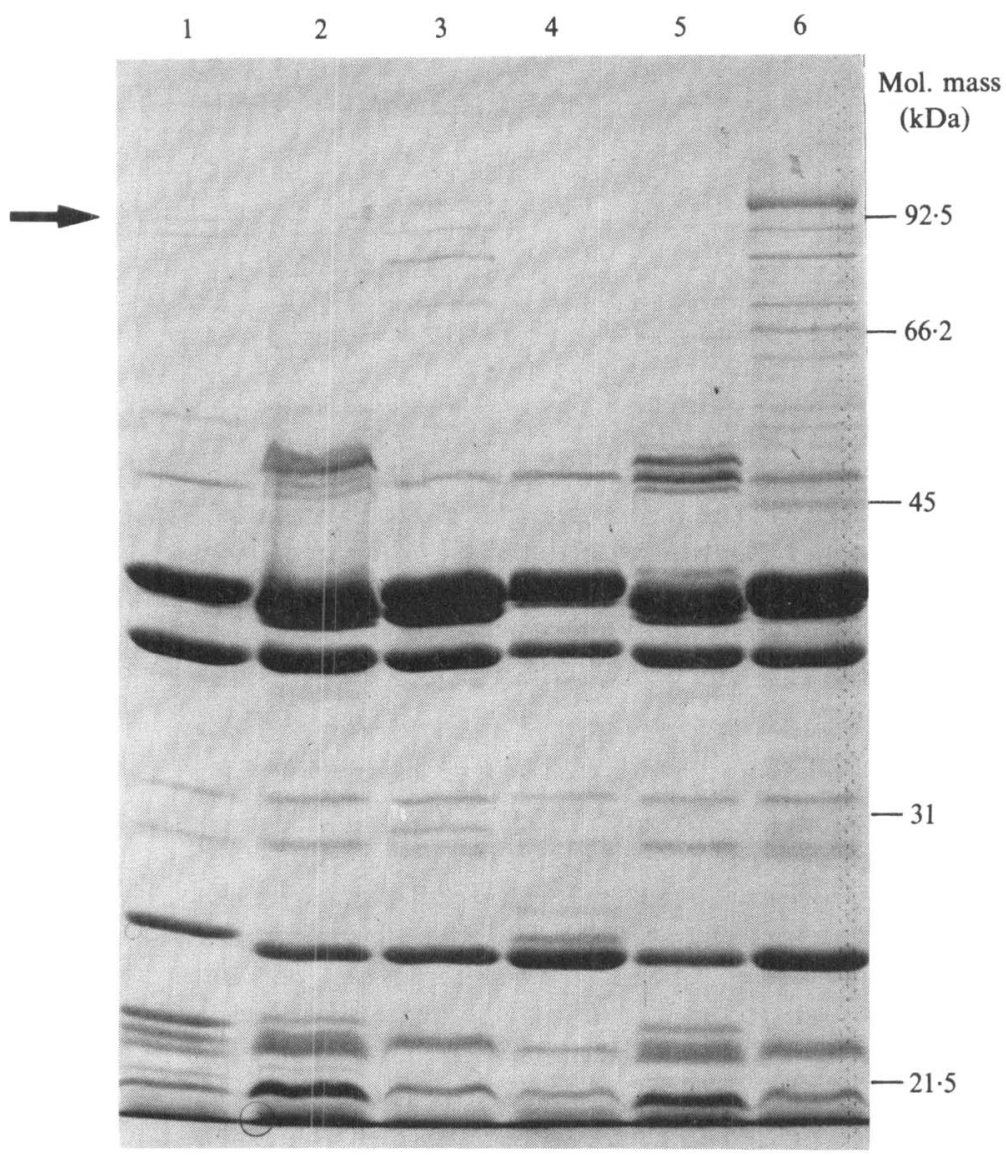

Fig. 1. SDS-PAGE profiles of OMPs of wild-type EPEC. Strains E2347/69 (O127:H6) (lane 1), E20517 (O111:H2) (lane 2) and E24582 (O142:H6) (lane 3) carrying pDEP1, pDEP2 and pDEP11, respectively, showing the expression of an OMP of $94 \mathrm{kDa}$ by each strain (arrowed). Strains 60R317 (lane 4) and 60R556 (lane 5) were derived by loss of pDEP1 and pDEP2 from the respective parent EPEC strains and did not express a $94 \mathrm{kDa}$ protein. Strain E24583 (O142: H6), which lacked pDEP11, expressed several proteins in the $94 \mathrm{kDa}$ region of the gel (lane 6), complicating the identification of a $94 \mathrm{kDa}$ OMP (lane 6). The protein load per lane was $30 \mu \mathrm{g}$. Protein molecular mass standards are shown on the right-hand side of the Figure.

The autotransferring plasmid F-Tc was used to mobilize plasmids from E2347/69 into $E$. coli $\mathrm{K} 12$. Six of ten transconjugants were $\mathrm{fi}^{+}$. Two $\mathrm{fi}^{+}$transconjugants, which both hybridized with the EAF probe, were examined further. Adherence to HEp-2 cells was examined after $6 \mathrm{~h}$ when cells showed a small number of clusters of less than 10 bacteria. The transconjugants contained a $60 \mathrm{MDa}$ plasmid as well as the F-Tc plasmid. No co-transfer of streptomycin or sulphonamide resistance occurred.

Tetracycline-sensitive derivatives of E20517 (58R689) and E24582 (60R718) were obtained by replica plating. Strain 58R689 was also sensitive to chloramphenicol and kanamycin but was still resistant to streptomycin and sulphonamides, while $60 \mathrm{R} 718$ had also lost resistance to ampicillin, chloramphenicol, kanamycin and sulphonamides. Plasmids in these strains were marked with ampicillin resistance by transposition of Tn801. Plasmid F-Tc was then transferred into the EPEC strains and used to mobilize the Tn801-marked plasmids. The E. coli K12 transconjugants from the crosses with both EPEC strains adhered to 3 to $5 \%$ of $\mathrm{HEp}-2$ cells with clusters of less than 10 bacteria and hybridized with the EAF probe. The EAF plasmid from E20517 (pDEP2) which was marked with Tn801 had a molecular mass of about 50 MDa (Table 2). No co-transfer of streptomycin or sulphonamide resistance occurred. The K12 transconju- 
Table 2. Properties of Tn801-marked EAF plasmids

Source of plasmid Mol. mass (MDa) fi

Autotransferability Incompatibility group
EAF plasmids

\begin{tabular}{|c|c|c|}
\hline pDEPI & pDEP2 & pDEP1l \\
\hline $\mathrm{E} 2347 / 69$ & E20517 & E24582 \\
\hline 60 & 50 & 61 \\
\hline$+v e$ & $-v e$ & $-v e$ \\
\hline $\begin{array}{l}\text { t ve } \\
\text { FI }\end{array}$ & - ve & - ve \\
\hline$F I_{\text {i:e }}$ and FIV & $\mathrm{F} I_{\text {me }}$ and FIV & $\mathrm{FI}_{\mathrm{me}}$ and FIV \\
\hline
\end{tabular}

gant from the cross with strain 60R718 carried a 40 MDa transfer factor, a 3.3 MDa plasmid and a $61 \mathrm{MDa}$ plasmid (pDEP11) as well as plasmid F-Tc. Plasmid pDEP11 was shown to be the EAF plasmid by Southern blotting with the EAF probe (result not shown).

None of the E. coli K12 transconjugants carrying an EAF plasmid expressed a $94 \mathrm{kDa}$ OMP (Fig. 2, lanes 2 to 4). None of them reacted with the O111-, O127- or O142-specific antisera. Long-chain LPS was not detected by SDS-PAGE of proteinase-K-digested E. coli K12 containing pDEP2.

\section{Properties of EAF plasmids}

The EAF plasmids from E2347/69 and E20517 were obtained in strains separately from the FTc factor by segregation experiments. A strain carrying pDEP11 and the $3.3 \mathrm{MDa}$ plasmid present in the original strain E24582 was obtained after crosses into a wild-type strain and subsequently $E$. coli $\mathrm{K} 12$ (see next section). The EAF plasmid from E2347/69 was marked with Tn 801 as previously described (pDEP1). Plasmid pDEP1 was autotransferring and able to mobilize the non-autotransferring factors NTP2 and NTP107 in crosses from E. coli K12 to E. coli $\mathrm{K} 12$, while $\mathrm{pDEP} 2$ and pDEP11 were non-autotransferring. Plasmid pDEP1 was $\mathrm{f}^{+}$ while pDEP2 and pDEP11 were not (Table 2).

The plasmids were tested for incompatibility with F-like plasmids. All the plasmids showed dual incompatibility with plasmids of incompatibility groups $F I V$ and $F I_{\text {me }}$, although there was no incompatibility with the plasmid F-Tc of incompatibility group FI. All the EAF plasmids were stable with a plasmid of incompatibility group FII.

Plasmid DNA prepared from $E$. coli $\mathrm{K} 12$ strains carrying the Tn801-marked EAF plasmids pDEP1, pDEP2 or pDEP1 1 was digested with restriction enzymes (Fig. $3 a$ ). The strain carrying pDEP11 also harboured the 3.3 MDa plasmid present in the original strain. Comparison of the fragment patterns obtained after digestion with BamHI plus SalI showed that the plasmids were distinguishable from each other, as expected from differences in their molecular mass and genetic properties. There were at least 12 fragments larger than $0.6 \mathrm{~kb}$ and several of these appeared to be of similar size in all the plasmids. To identify the region hybridizing to the EAF probe, separated plasmid DNA restriction fragments were blotted onto nylon membranes and probed with the $1 \mathrm{~kb} \mathrm{BamHI-Sall}$ DNA fragment of pMAR2 under high stringency conditions (Fig. $3 b$ ). As expected plasmid pDEP1 contained a $1 \mathrm{~kb}$ Sall-BamHI fragment homologous to the probe fragment and this fragment was also present in pDEP11. However, the EAF probe hybridized to a larger fragment $(4 \mathrm{~kb})$ in Sall plus BamHI digests of pDEP2 and no $1 \mathrm{~kb}$ fragment was detected (Fig. $3 b$, tracks 1 to 4). In both pDEP1 and pDEP11, the EAF probe hybridized with a $5.9 \mathrm{~kb} E c o$ RV fragment (tracks 5 and 7) and the PvuII fragments detected by the probe were also of similar size (6.1 kb in pDEP1 and $6.4 \mathrm{~kb}$ in pDEP11; tracks 8 and 10$)$. EcoRV and PvuII digests of pDEP2 showed two hybridizing bands: these were EcoRV fragments of $5.8 \mathrm{~kb}$ and $2.8 \mathrm{~kb}$ and $P v u I I$ fragments of $5.4 \mathrm{~kb}$ and $3.9 \mathrm{~kb}$ (tracks 6 and 9). The target of the EAF probe in $\mathrm{pDEP} 2$ appeared to differ in the presence of some restriction enzyme sites from that in pDEP1 and pDEP11, but not to the extent that would affect hybridization under stringent conditions. This was not due to the presence of the transposon marker, since identical results were obtained with digests of plasmid DNA from the wild-type strain 58R689 containing the unmarked EAF plasmid. 


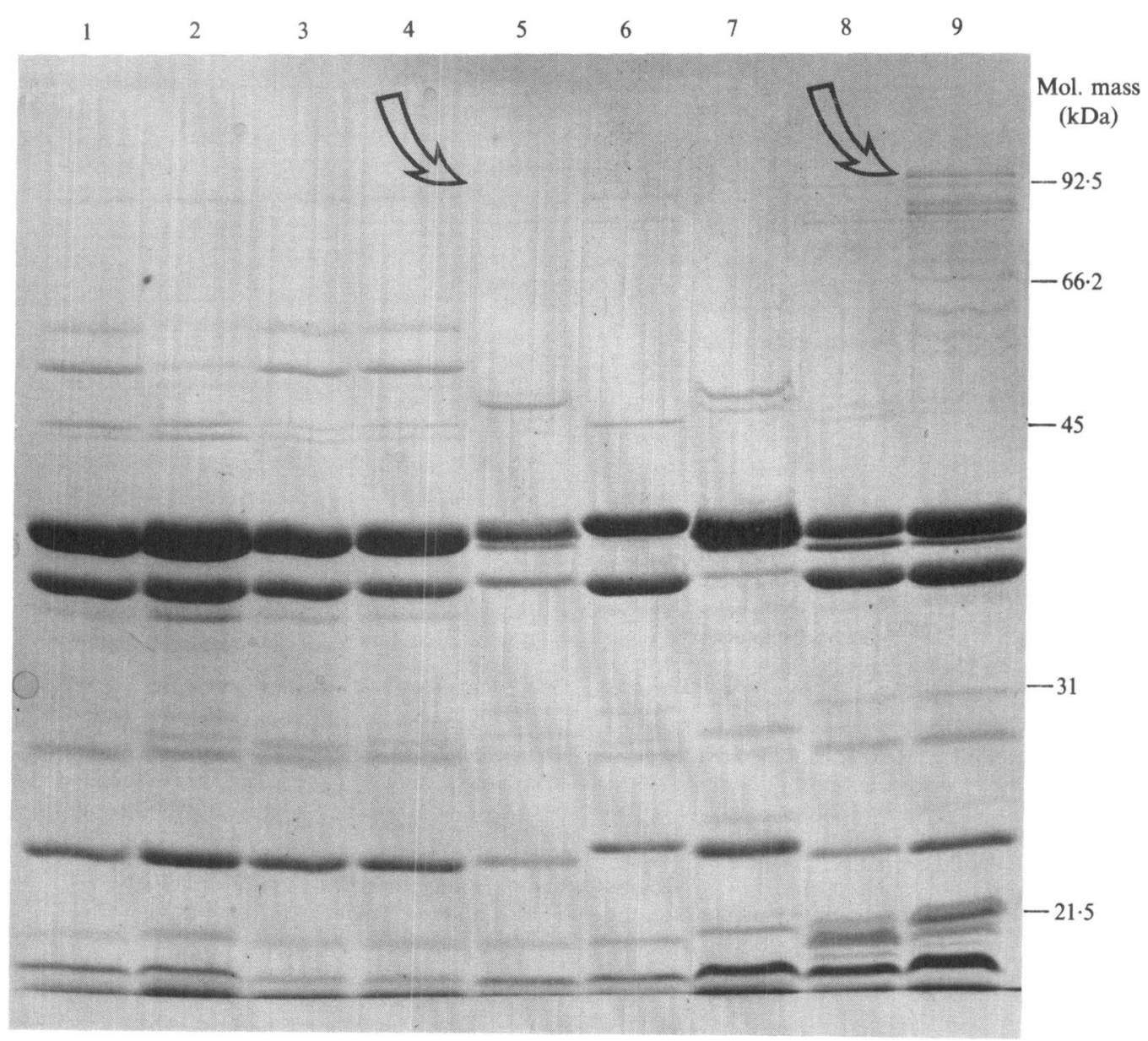

Fig. 2. SDS-PAGE profiles of OMPs of transconjugants carrying plasmids pDEP1, pDEP2 and pDEP11. E. coli K 12 strain 14R519 harbouring pDEP1, pDEP2 and pDEP11 (lanes 2 to 4, respectively) did not contain an OMP of $94 \mathrm{kDa}$. The profile of the plasmid-free K12 host is shown in lane 1 . Strain 60R556 (O111:H2) carrying pDEP1 and strain 60R317 (O127:H6) carrying pDEP2 expressed an OMP of $94 \mathrm{kDa}$ (arrowed in lanes 5 and 6) whereas strain 60R556 carrying pDEP1l did not express a $94 \mathrm{kDa}$ OMP (lane 7). Strain E27657 (O128:H2) carrying pDEP1 did not express an OMP of $94 \mathrm{kDa}$ (lane 8); however, this strain carrying pDEP2 did express a $94 \mathrm{kDa}$ OMP (lane 9). The protein load per lane was $30 \mu \mathrm{g}$. Protein molecular mass standards are shown on the right-hand side of the Figure.

\section{Isolation of HEp-2 non-adherent derivatives of EPEC}

A variant of E2347/69 which had lost the EAF plasmid was obtained by transferring the FIV plasmid TP129 into the parent strain. Colonies of E2347/69 (TP129) were examined for loss of HEp-2 adherence and loss of ability to hybridize with the EAF probe. An EAF-plasmidnegative colony was obtained with reduced ability to adhere to HEp-2 cells and TP129 was lost from this colony to give derivative $60 \mathrm{R} 317$ (Table 1). In a similar way TP129 was introduced into the tetracycline-sensitive derivative of E20517, which contained pDEP2. Colonies were tested for loss of ampicillin resistance. An ampicillin-sensitive segregant had reduced ability to adhere to HEp- 2 cells, and had lost the plasmid which coded for EAF. TP129 was lost from this strain to give derivative 60R556 (Table 1). 60R556 still expressed the O111-specific side-chain of the LPS. Neither of the EAF-plasmid-negative variants expressed the $94 \mathrm{kDa}$ OMP (Table 3; Fig. 1, lanes 4 to 6 ). 
(a)

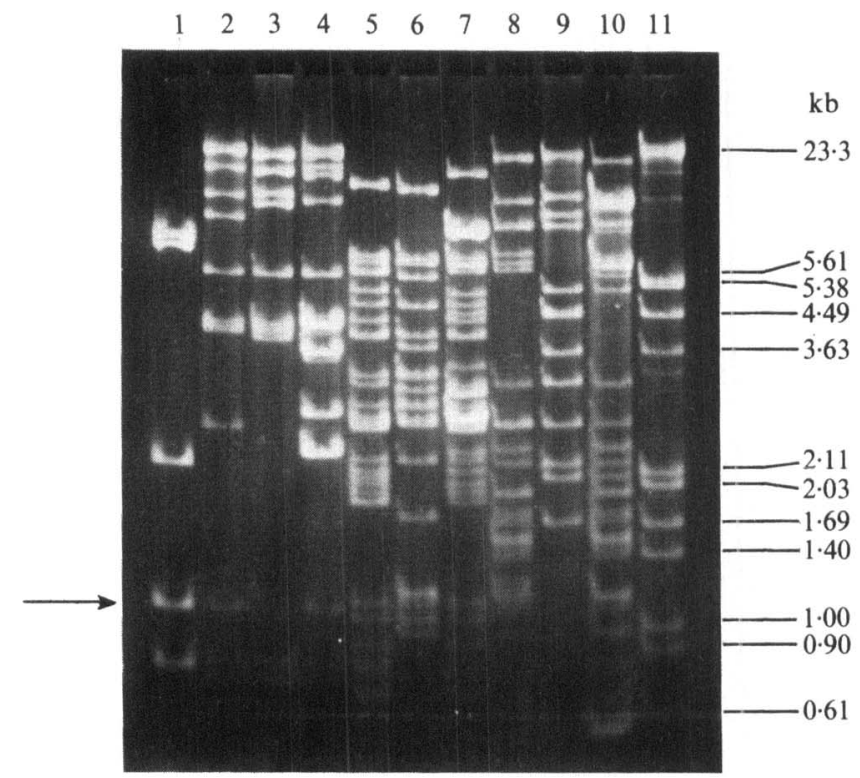

(b)

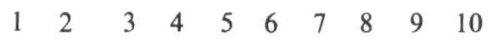

Fig. 3. Restriction enzyme digests and Southern blot analyses of EAF plasmids from EPEC strains. (a) Restriction enzyme digests. Fragments of purified plasmid DNA were separated by electrophoresis on a $1 \%(w / v)$ agarose gel (Willshaw et al., 1985). Track 1 shows a $S a l I+B a m H I$ digest of pMAR22 to indicate the $1 \mathrm{~kb}$ EAF probe fragment (arrowed). Tracks 2 to 4 Sall + BamHI digests of pDEP1, pDEP2 and pDEP11; tracks 5 to 7 EcoRV digests of pDEP1, pDEP2 and pDEP11; tracks 8 to 10 PvuII digests of pDEP1, pDEP 2 and pDEP11. Track 11 shows phage $\lambda$ DNA digested with EcoRI + HindIII, with sizes of fragments $(\mathrm{kb})$ on the right-hand side. (b) Autoradiogram showing hybridization of the ${ }^{35} \mathrm{~S}$ labelled EAF probe with a Southern blot of the gel shown in (a). Tracks 1 to 10 are as above.

\section{Transfer of EAF plasmids into E. coli of different serotypes}

The recipient strains included an EAF-negative strain of EPEC serotype O128:H2, EAFplasmid-negative variants of E. coli $\mathrm{O} 111: \mathrm{H} 2$, and $0127: \mathrm{H} 6$, all of which showed slight adherence to HEp-2 cells, and also E. coli of serotypes $\mathrm{O} 40: \mathrm{H} 3, \mathrm{O} 71: \mathrm{H} 48$ and $\mathrm{O} 99: \mathrm{H} 4$ isolated from healthy individuals (Table 3). After transfer of the EAF plasmid its presence in the recipient was confirmed by plasmid DNA content and recipient strains were positive in colony hybridization with the EAF probe. When the transconjugants of EPEC serotypes were examined for adherence to HEp-2 cells all showed a high level of adherence (Table 3). Strains of serotypes $\mathrm{O} 111: \mathrm{H} 2$ and $\mathrm{O} 127: \mathrm{H} 6$ carrying pDEP1 and pDEP2, respectively, expressed OMPs of $94 \mathrm{kDa}$ (Table 3 ; Fig. 2, lanes 5 and 6) which reacted with the antiserum raised to the $94 \mathrm{kDa}$ OMP of strain E20513 (see Methods). Variant 60R556 carrying pDEP11 was HEp-2 adherent (Table 3) but an OMP of $94 \mathrm{kDa}$ was not expressed (Fig. 2, lane 7) and an immunoblot reaction was not detected. Strain E27657 (O128: H2) carrying pDEP1 did not express a protein of $94 \mathrm{kDa}$ and an immunoblot reaction was not observed (Table 3; Fig. 2, lane 8). When pDEP2 was introduced into E27657 a $94 \mathrm{kDa}$ OMP was expressed which reacted with the antiserum (Table 3; Fig. 2, lane 9); similarly, pDEP11 in E27657 also expressed an OMP of $94 \mathrm{kDa}$ but this protein did not react by immunoblot (Table 3, profile not shown).

The EAF plasmids in the E. coli from healthy individuals either did not confer the ability to adhere to HEp- 2 cells or resulted in adhesion at a low level. None of the strains expressed the 94 $\mathrm{kDa}$ OMP and an immunoblot reaction was not detected (Table 3). When the plasmids were transferred out of these $E$. coli into $E$. coli $\mathrm{K} 12$ and then into strain $60 \mathrm{R} 317$, the ability to adhere in large numbers to HEp-2 cells was restored to this strain. 
Table 3. Properties of E. coli strains containing Tn801-marked EAF plasmids

\begin{tabular}{|c|c|c|}
\hline \multicolumn{2}{|c|}{ Host strain } & \multirow{2}{*}{$\begin{array}{l}\text { Plasmi } \\
\text { presen }\end{array}$} \\
\hline No. & Serotype & \\
\hline $14 \mathrm{R} 519$ & $\mathrm{O}$ rough $: \mathrm{H} 48$ & $\left\{\begin{array}{l}\text { None } \\
\text { pDEP1 } \\
\text { pDEP2 } \\
\text { pDEP11 }\end{array}\right.$ \\
\hline $60 \mathrm{R} 556$ & $\mathrm{O} 111: \mathrm{H} 2$ & $\begin{array}{l}\text { None } \\
\text { pDFP }\end{array}$ \\
\hline $\begin{array}{l}\text { E20517 } \\
\text { 60R556 }\end{array}$ & $\begin{array}{l}\mathrm{O} 111: \mathrm{H} 2 \\
\mathrm{O} 111: \mathrm{H} 2\end{array}$ & $\begin{array}{l}\text { pDEP2 } \\
\text { pDEP11 }\end{array}$ \\
\hline $\begin{array}{l}60 R 317 \\
\text { E2347/69 } \\
60 R 317\end{array}$ & $\begin{array}{l}\mathrm{O} 127: \mathrm{H} 6 \\
\mathrm{O} 127: \mathrm{H} 6 \\
\mathrm{O} 127: \mathrm{H} 6\end{array}$ & $\begin{array}{l}\text { None } \\
\text { pDEP1 } \\
\text { pDEP2 }\end{array}$ \\
\hline E27657 & $\mathrm{O} 128: \mathrm{H} 2$ & $\left\{\begin{array}{l}\text { None } \\
\text { pDEP1 } \\
\text { pDEP2 } \\
\text { pDEP11 }\end{array}\right.$ \\
\hline E2722/1 & $\mathrm{O} 40: \mathrm{H} 3$ & $\left\{\begin{array}{l}\text { None } \\
\text { pDEP1 } \\
\text { pDEP2 }\end{array}\right.$ \\
\hline E2698/1 & $\mathrm{O} 71: \mathrm{H} 48$ & $\left\{\begin{array}{l}\text { None } \\
\text { dDEP1 } \\
\text { pDEP2 }\end{array}\right.$ \\
\hline E2939/3 & $\mathrm{O} 99: \mathrm{H} 4$ & $\left\{\begin{array}{l}\text { None } \\
\text { pDEP1 } \\
\text { pDEP2 }\end{array}\right.$ \\
\hline
\end{tabular}

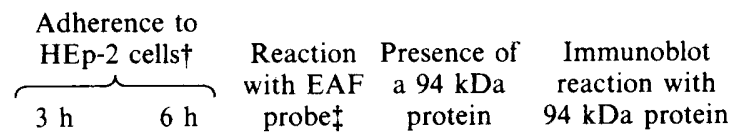

NT, Not tested.

$\dagger, \ddagger$ See corresponding footnotes to Table 1.

\section{DISCUSSION}

The EAF plasmid pDEP1 differed from the other two EAF plasmids in being $\mathrm{f}^{+}$and autotransferring. However, the EAF plasmids were all incompatible with an $F I_{\text {me }}$ plasmid TP160 and an FIV plasmid TP129 but showed no incompatibility with plasmid F-Tc. The genes and sites required for autonomous replication and its control constitute the basic replicons of plasmids. Several replicons are common in plasmids belonging to inc $\mathrm{F}$ groups (Couturier et al., 1988) which may account for the dual incompatibility. The replicons present in $\mathrm{F}$ factor, an $\mathrm{FI}_{\mathrm{me}}$ plasmid and plasmid pDEP1 are different (Couturier et al., 1988; W. Maas, personal communication), which may account for the finding that the present EAF plasmids were compatible with plasmid F-Tc but incompatible with plasmid TP160. Nataro et al. (1987b) reported that EAF plasmid pMAR2, which was isolated from a strain from the same outbreak as the strain yielding plasmid pDEP1, was incompatible with plasmid R1 of the FII incompatibility group when the experiment was done in the wild-type strain. In contrast, plasmid pDEP1 was compatible with plasmid R1-16, a derivative of R1, in E. coli $\mathrm{K} 12$ although its properties were otherwise identical to the published properties of pMAR2 (Baldini et al., 1983; Nataro et al., 1987a). We cannot explain this discrepancy. None of the EAF plasmids we transferred encoded drug resistance or the expression of $\mathrm{O}$ antigens in contrast to the findings of Laporta et al. (1986) and Riley et al. (1987). Plasmid pDEP2 from an EPEC of serotype O111: $\mathrm{H} 2$ with a molecular mass of about $46 \mathrm{MDa}$ was smaller than the $54 \mathrm{MDa}$ plasmid transferred from a strain of serotype $\mathrm{O} 111: \mathrm{H}^{-}$by Riley et al. (1987).

It was recently reported that strains belonging to a number of traditional EPEC serogroups, and carrying EAF plasmids, adhered avidly to HEp-2 cells and generally expressed an OMP of 
$94 \mathrm{kDa}$. Also, EPEC strains cured of an EAF plasmid exhibited greatly reduced HEp-2 adhesion, and lacked a $94 \mathrm{kDa}$ OMP (Chart et al., 1988). The presently observed inability of $\mathrm{K} 12$ and non-EPEC transconjugants to express full HEp-2 adhesion, correlated with the lack of expression of detectable levels of a $94 \mathrm{kDa}$ OMP, suggests that HEp-2 adherent EPEC may require additional genetic information to that encoded by an EAF plasmid for the complete assembly of the HEp-2 adhesion mechanism. EPEC strains 60R556, 60R317 and E27657, which adhere only weakly to HEp-2 cells, became fully HEp-2 adhesive regardless of which EAF plasmid (pDEP1, 2 or 11 ) they received. Nevertheless, plasmids pDEP1 and pDEP2 appear to be different from pDEP11 since $94 \mathrm{kDa}$ proteins were expressed by recipients of pDEP1 and pDEP2, and these proteins were antigenically similar. In contrast, strain 60R556 carrying pDEP11 did not express a $94 \mathrm{kDa}$ OMP and E27657 carrying pDEP11 produced a $94 \mathrm{kDa}$ OMP that did not react with the antiserum. Knutton et al. $(1987 a, b)$ have suggested that EPEC adhesion involves a two step process consisting of an initial binding to the eukaryotic cell surface, possibly mediated by a putative fimbrial adhesin, followed by attachment involving close cell-to-cell contact. Thus, full HEp- 2 adhesion may be mediated by two distinct genetic determinants, one of which is associated with an EAF plasmid and the other possibly chromosomally located.

The absence of a $94 \mathrm{kDa}$ OMP in K 12 and non-EPEC transconjugants suggests that these strains were unable to synthesize this protein, which might explain the observed reduction in HEp- 2 adhesion. In contrast, the inability of HEp-2 adherent strain 60R556 carrying pDEP11 and strain E27657 carrying pDEP1 to express an OMP of $94 \mathrm{kDa}$ is more difficult to explain. Proteolytic degradation might be responsible (Chart et al., 1988), although outer membranes were prepared in the presence of a protease inhibitor. However, if indeed a $94 \mathrm{kDa}$ OMP was not being expressed by these strains, a role for this OMP in HEp-2 adhesion is put into question.

Identification of EPEC by serotyping or HEp-2 adherence ability poses problems either because of the non-availability of diagnostic antisera or the technical problems associated with tissue culture. An alternative method of screening for EPEC by using a DNA probe for EAF has been proposed. Two surveys showed complete correlation between the presence of the EAF genes and ability to adhere to HEp-2 or HeLa cells (Nataro et al., $1985 \mathrm{a}$; Chatkaemorakot $\mathrm{et}$ al., 1987). In a recent survey Levine et al. (1988) isolated some non-EPEC O group strains which hybridized with the DNA probe for EAF. These strains were as common in controls as in patients suggesting that they might not be pathogenic. It was not stated if they adhered to HEp-2 cells. We have shown that $E$. coli $\mathrm{K} 12$ or some non-EPEC $E$. coli strains carrying the EAF plasmid do not adhere to HEp-2 tissue culture cells. Thus it is possible that HEp-2 non-adherent, non-EPEC wild-type strains exist and that they will be detected when strains are screened with the DNA probe for EAF.

\section{REFERENCES}

Anderson, E. S. \& Threl.fall., E. J. (1974). The characterisation of plasmids in the enterobacteria. Journal of Hygiene 72, 471-487.

Anderson, E. S., Threlfall, E. J., Carr, J. M., McConnell, M. M. \& SMith, H. R. (1977). Clonal distribution of resistance plasmid-carrying Salmonella typhimurium, mainly in the Middle East. Journal of Hygiene 79, 425-448.

Baldini, M. M., KaPer, J. B., Levine, M. M., Candy, D. C. A. \& Moon, H. W. (1983). Plasmid-mediated adhesion in enteropathogenic Escherichia coli. Journal of Pediatric Gastroenterology and Nutrition 2, 534538.

Birnborm, H. C. \& Doly, J. (1979). A rapid alkaline extraction procedure for screening recombinant plasmid DNA. Nucleic Acids Research 7, 1513-1523.
Chart, H. \& Griffiths, E. (1985). Antigenic and molecular homology of the ferric enterobactin receptor protein of Escherichia coli. Journal of General Microbiology 131, 1503-1509.

Chart, H., Scotland, S. M., Willshaw, G. A. \& ROWE, B. (1988). HEp-2 adhesion and the expression of a $94 \mathrm{kDa}$ outer membrane protein by strains of Escherichia coli belonging to enteropathogenic serogroups. Journal of General Microbiology 134, 1315-1321.

Chatkaemorakot, A., Echeverria, P., Taylor, D. N., Bettelheim, K. A., Blacklow, N. R., Sethabutr, O., Seriwatana, J. \& KaPer, J. (1987). Hela cell-adherent Escherichia coli in children with diarrhea in Thailand. Journal of Infectious Diseases 156, 669-672. 
Couturier, M., Bex, F., Bergouist, P. L. \& MaAs, W. K. (1988). Identification and classification of bacterial plasmids. Microbiological Reviews 52, 375395.

Cravioto, A., Gross, R. J., Scotland, S. M. \& Rowe, B. (1979). An adhesive factor found in strains of Escherichia coli belonging to the traditional infantile enteropathogenic serotypes. Current Microbiology 3, 95-99.

Echeverria, P., Taylor, D. N., Donohue-Rolfe, A., SupaWat, K., Ratchtrachenchai, O., KaPER, J. \& KeusCH, G. T. (1987). HeLa cell adherence and cytotoxin production by enteropathogenic Escherichia coli isolated from infants with diarrhea in Thailand. Journal of Clinical Microbiology 25, 15191523.

Edelman, R. \& Levine, M. M. (1983). Summary of a workshop on enteropathogenic Escherichia coli. Journal of Infectious Diseases 147, 1108-1118.

Feinberg, A. P. \& Vogelstein, B. (1983). A technique for radiolabelling DNA restriction endonuclease fragments to high specific activity. Analytical Biochemistry 132, 6-13.

FRÉDÉRICQ, P. (1957). Colicins. Annual Review of Microbiology 11, 7-22.

Frydman, A. \& Meynell, E. (1969). Interactions between derepressed F-like R factors and wild-type colicin B factors: superinfection immunity and repressor susceptibility. Genetical Research 14, 315332.

Gerards, L. J., Hennekam, R. C. M., V. Dijk, W. C., RoORD, J. J. \& FleER, A. (1984). An outbreak of gastroenteritis due to Escherichia coli $\mathrm{O} 142 \mathrm{H} 6$ in a neonatal department. Journal of Hospital Infection $\mathbf{5}$, 283-288.

Griffiths, E., Stevenson, P., Hale, T. L. \& Formal, S. B. (1985). The synthesis of aerobactin and a 76,000 dalton iron-regulated outer membrane protein by Escherichia coli K12-Shigella flexneri hybrids and by enteroinvasive strains of Escherichia coli. Infection and Immunity 49, 67-71

Gross, R. J. \& Rowe, B. (1985). Escherichia coli diarrhoea. Journal of Hygiene 95, 531-550.

HedGes, R. W. \& Datta, N. (1972). R124, an fi ${ }^{+}$R factor of a new compatibility class. Journal of General Microbiology 71, 403-405.

Hiтchсоск, P. J. \& Brown, T. M. (1983). Morphological heterogeneity among Salmonella lipopolysaccharide chemotypes in silver-stained polyacrylamide gels. Journal of Bacteriology 154, 269-277.

KnUtTon, S., Baldini, M. M., KaPER, J. B. \& MCNeISH, A. S. (1987a). Role of plasmid-encoded adherence factor in adhesion of enteropathogenic Escherichia coli to HEp-2 cells. Infection and Immunity 55, 78-85.

Knutton, S., Lloyd, D. R. \& McNeish, A. S. (1987b). Adhesion of enteropathogenic Escherichia coli to human intestinal enterocytes and cultured human intestinal mucosa. Infection and Immunity 55, 69-77.

LAEMMLI, U. K. (1970). Cleavage of structural proteins during the assembly of the head of bacteriophage T4. Nature, London 227, 680-685.

LAPORTA, M. Z., Silva, M. L. M., Scaletsky, I. C. A. \& TRABULSI, L. R. (1986). Plasmids coding for drug resistance and localized adherence to HeLa cells in enteropathogenic Escherichia coli $\mathrm{O} 55: \mathrm{H}^{-}$and
O55:H6. Infection and Immunity 51, 715-717.

Levine, M. M., Nataro, J. P., Karch, H., Baldini, M. M., KAPER, J. B., BlaCK, R. E., Clements, M. L. \& O'BRIEN, A. D. (1985). The diarrheal response of humans to some classic serotypes of enteropathogenic Escherichia coli is dependent on plasmid encoding an enteroadhesive factor. Journal of Infectious Diseases 152, 550-559.

Levine, M. M., Prado, V., Robins-Browne, R., Lior, H., Kaper, J. B., Moseley, S. L., Gicquelais, K., Nataro, J. P., Vial, P. \& Tall, B. (1988). Use of DNA probes and HEp-2 cell adherence assay to detect diarrheagenic Escherichia coli. Journal of Infectious Diseases 158, 224-228.

Maniatis, T., Fritsch, E. F. \& SambrooK, J. (1982). Molecular Cloning: A Laboratory Manual. Cold Spring Harbor, NY: Cold Spring Harbor Laboratory.

McConnell, M. M., Willshaw, G. A., Smith, H. R., Scotland, S. M. \& Rowe, B. (1980). Plasmids coding for heat-labile enterotoxin production isolated from Escherichia coli O78: comparison of properties. Journal of Bacteriology 143, 158-167.

Nataro, J. P., Baldini, M. M., KaPER, J. B., Black, R. E., Bravo, N. \& Levine, M. M. (1985a). Detection of an adherence factor of enteropathogenic Escherichia coli with a DNA probe. Journal of Infectious Diseases 152, 560-565.

Nataro, J. P., Scaletsky, I. C. A., Kaper, J. B., Levine, M. M. \& Trabulsi, R. I. (1985b). Plasmidmediated factors conferring diffuse and localized adherence of enteropathogenic Escherichia coli. Infection and Immunity 48, 378-383.

Nataro, J. P., Kaper, J. B., Robins-Browne, R., Prado, V., Vial, P. \& Levine, M. M. (1987a). Patterns of adherence of diarrheagenic Escherichia coli to HEp-2 cells. Paediatric Infectious Diseases Journal 6, 829-831.

Nataro, J. P., Maher, K. O., Mackie, P. \& KaPer, J. B. $(1987 b)$. Characterization of plasmids encoding the adherence factor of enteropathogenic Escherichia coli. Infection and Immunity 55, 2370-2377.

Riley, L. W., Junio, L. N., Libaek, L. B. \& SchOOLNIK, G. K. (1987). Plasmid-encoded expression of lipopolysaccharide $\mathrm{O}$-antigenic polysaccharide in enteropathogenic Escherichia coli. Infection and Immunity 55, 2052-2056.

Robinson, M. K., Bennett, P. M., Falkow, S. \& DoDD, H. E. (1980). Isolation of a temperaturesensitive derivative of RPI. Plasmid 3, 343-347.

Scaletsky, I. C. A., Silva, M. L. M. \& Trabulsi, L. R. (1984). Distinctive patterns of adherence of enteropathogenic Escherichia coli to HeLa cells. Infection and Immunity 45, 534-536.

Scotland, S. M., Richmond, J. E. \& Rowe, B. (1983). Adhesion of enteropathogenic strains of Escherichia coli (EPEC) to HEp-2 cells is not dependent on the presence of fimbriae. FEMS Microbiology Letters 20 , 191-195.

Smith, H. R., Scotland, S. M. \& Rowe, B. (1983). Plasmids that code for production of colonization factor antigen II and enterotoxin production in strains of Escherichia coli. Infection and Immunity 40 , 1236-1239.

SoUtherN, E. M. (1975). Detection of specific sequences among DNA fragments separated by 
agarose gel electrophoresis. Journal of Molecuiar Biology 98, 503-517.

TAYLOR, J. (1961). Host-specificity and enteropathogenicity of Escherichia coli. Journal of Applied Bacteriology 24, 316-325.

TsaI, C.-M. \& Frasch, C. E. (1982). A sensitive silver strain for detecting lipopolysaccharide in polyacrylamide gels. Analytical Biochemistry 119, 115-119.

Willshaw, G. A., Smith, H. R., Scotland, S. M. \& Rowe, B. (1985). Cloning of genes determining the production of Vero cytotoxin by Escherichia coli. Journal of General Microbiology 131, 3047-3053. 